Acta vet. scand. 1961, 2, 199-209.

From the Department of Obstetrics \& Gynaecology, Royal Veterinary College, Stockholm.

\title{
TESTICULAR HYPOPLASIA WITH MULTIPOLAR SPINDLE FORMATION IN THE SPERMIOCYTES OF THE BULL
}

By

Odd Knudsen.

Through in-breeding in some Swedish lines of the HolsteinFrisian breed, various types of reproductive disorders have become manifest. Lagerlöf $(1934,1948)$ examined many bulls of this breed clinically and histologically and in several animals could demonstrate testicular hypoplasia. As a further step in the study of this lesion, the testicles of several affected bulls have been examined cytogenetically and the results briefly reported (Knudsen 1958). In three of these bulls spermiogenesis was characterised by multipolar spindle formation in the spermiocytes. Although only 3 bulls with this particular defect have been encountered, they form a clinical and cytogenetical entity which will be described in this paper.

Multipolar spindle formation in plants can be produced experimentally by treatment with toxic substances (Sakamura 1920 among others) or by changes in temperature (Ehrenberg \& Östergren 1942) or in pressure (Pease 1946). Most studies of multipolar spindle formation, however, have been carried out on hybrids of plants and Drosophilia (see Heitz 1926, Beadle \& Mc Clintock 1928, Koller 1934, Schrader 1941, and Walters 1958, and others). Particularly Walters (1960) has attempted to elucidate chromosomal behaviour, spindle organization, and cell division during meiosis with multipolar spindle formation in interspecific hybrids of Bromus.

Apart from these studies on bulls it would seem that multipolar spindle formation in mammals has been demonstrated only in human cancer cells (Therman \& Timonen 1954).

Supported by a grant from Statens medicinska forskningsråd and Jordbrukets forskningsråd. 


\section{MATERIAL}

The three bulls on which these studies are based, to be referred to as 145,147 and 172, were aged between $1 \frac{1}{2}$ and 3 years. All were of the Swedish Lowland breed (Holstein-Frisian) and had been rejected as breeders because of sterility or poor semen quality. The bulls 145, and 147 were each bred more than 20 times but according to the owner, only 145 proved fertile to the degree of producing 2 pregnancies. This information has been referred to the animal husbandryman of the county who considers it impossible that any other bull could have sired these calves. No pregnancies resulted from the services by bull 147. Bull 172 has served only in artificial vagina.

The 3 bulls belong to the same line. Two have the same sire and all 3 have a common sire's dam which in turn is related to all 3 dams. The degree of inbreeding calculated by Wright's scale is $0.09-0.10$ for the 3 bulls. The animals were raised in a wellmanaged herd which has supplied a large number of fertile bulls.

\section{METHODS}

These bulls were maintained in the clinic of the department for at least 4 months. During this time the general health status and the sexual organs of the bulls were repeatedly examined.

At least 20 semen samples from each bull were collected in an artificial vagina. The volume of ejaculate was measured. If sperm were present in a sample, their morphology was evaluated by the standards developed by Lagerlöf (1934).

Immediately upon collection the ejaculate was centrifuged and the sediment fixed in methanol or acetic-alcohol $(1: 3)$ either before centrifugation or immediately after smearing on a glass slide. The smears were stained with Gomori's or Mayer's haematoxylin; in some instances the smears were counterstained with eosin.

Immediately after castration small blocks of testicular tissue were fixed in acetic-alcohol (1:3). Squash preparations were stained with Gomori's haematoxylin (Melander-Wingstrand 1953) and histological sections with Gomori's haematoxylin and fast green (Knudsen 1954).

The bulls were slaughtered within a day after castration. At this time the accessory sexual organs, hypophysis, thyroid, parathyroids, and adrenals could be examined. 


\section{RESULTS}

Clinical examination

Apart from their sexual organs the bulls were normally developed and showed no signs of disease.

These bulls had an unusually strong libido and were difficult to restrain as they were led up to the teaser. Moderate, bilateral testicular hypoplasia without discernible difference between the members of a pair could be demonstrated. The consistency was normal. No gross abnormalities were seen in the epididymides and accessory sexual organs.

\section{Examination of the ejaculate}

The ejaculates of all 3 bulls were quite similar in all respects. The volume varied between 1.5 and $5 \mathrm{ml}$; the samples were watery, sometimes with a greyish-white opalescent colour. If sperm were present at all, their number never exceeded $1000 / \mathrm{mm}^{3}$. The sperm concentration was too low to permit reliable estimation of the incidence of abnormal forms; most of these which could be seen were morphologically normal. A few giant cells were viable in fresh unfixed smears.

The microscopical appearance of the centrifuged and stained sediment differed from that encountered in other types of testicular hypoplasia in bulls, even closely related types seen in bulls of the same breed. What characterised the ejaculate sediment of the bulls dealt with here were the giant cells of a particular appearance as well as pyknotic nuclei, anuclear cell fragments, and a few sperm, usually normal (Fig. 1). The giant cells with their 2 to more than 10 nuclei had a distinct cell membrane. Their nuclei varied greatly in size but were seldom larger than those of a spermid. Through their round shape and their finely granular chromatin, the nuclei of the giant cells resembled those of spermids with relatively sparse chromatin (Fig. 2). Nuclear morphology, however, was often distorted by degeneration. The degenerated nuclei of the giant cells rarely had the homogeneous structure generally seen in pyknosis and which is evident in the free pyknotic nuclei in the ejaculate. As a rule the nuclei were gathered in the centre of the cells but occassionally filled out most of the cytoplasm. 


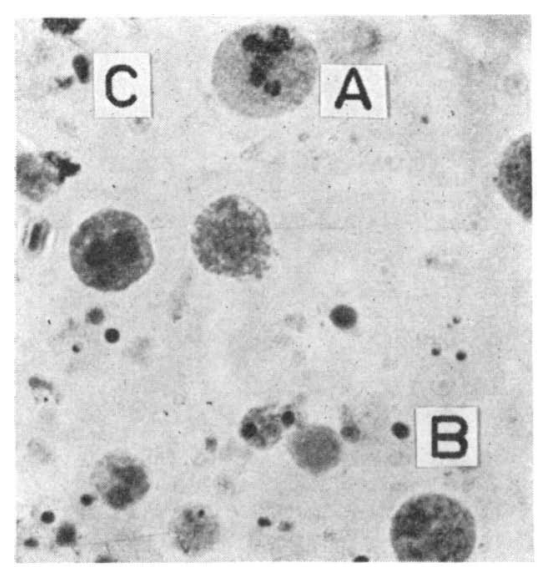

F i g. 1.

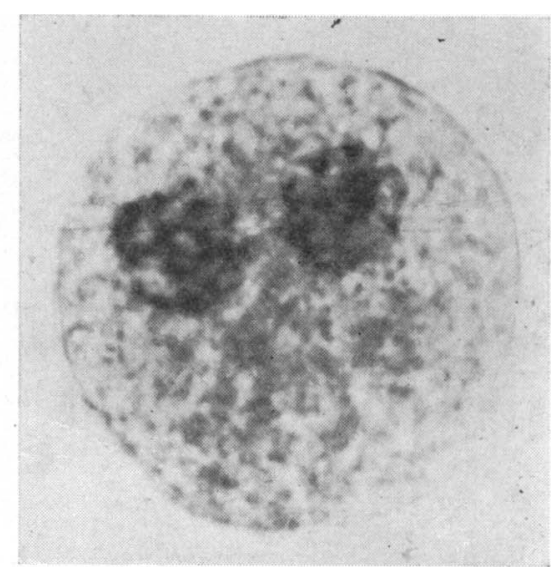

F i g. 2.

F i g. 1. Semen centrifugate from a bull with multipolar spindles in the spermiocytes.

A. Giant cell

B. Pyknotic nuclei

C. Sperm. Due to the thick preparate caused by the giant cells the tail of the sperm as well as some nuclei are not in focus (approx. $300 \times)$.

F i g. 2. Giant cell containing a common type of nuclei

(approx. $1500 \times$ ).

Morphological examination

No macroscopical changes were seen in any of the bulls at slaughter.

\section{Cytogenetical examination}

The most obvious abnormality in low-power views of the testicles is the presence of all types of germinal epithelial cells but no sperm formation, i. e. arrested spermiogenesis (Nelson 1950, Sniffen et al. 1950). A characteristic feature is the clumping of the chromosomes of the spermiocytes into several small groups (Fig. 3). In some tubuli, solitary pyknotic nuclei or groups of such nuclei are situated towards the lumen. Other tubuli contain giant cells with a well-developed cell membrane and nuclei resembling those of spermids (Fig. 4).

Spermiocytogenesis can be followed through the normal course up to prophase in the primary spermiocytes. During initial stages of metaphase, the premetaphasic stretch (Knudsen 


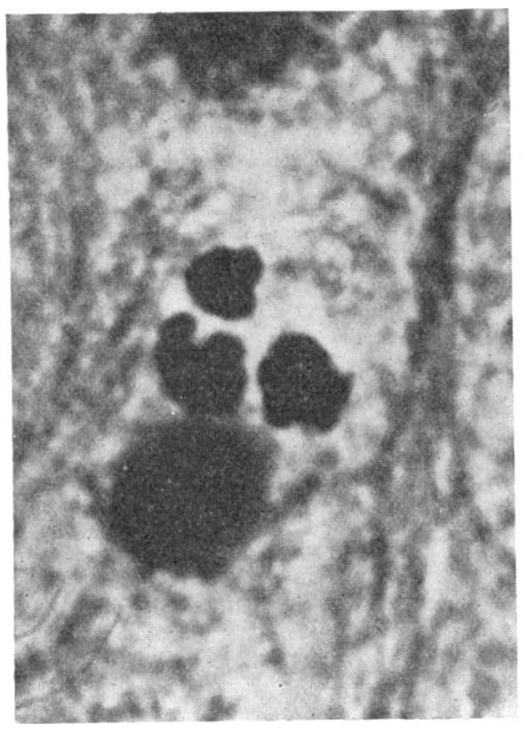

F i g. 3 .

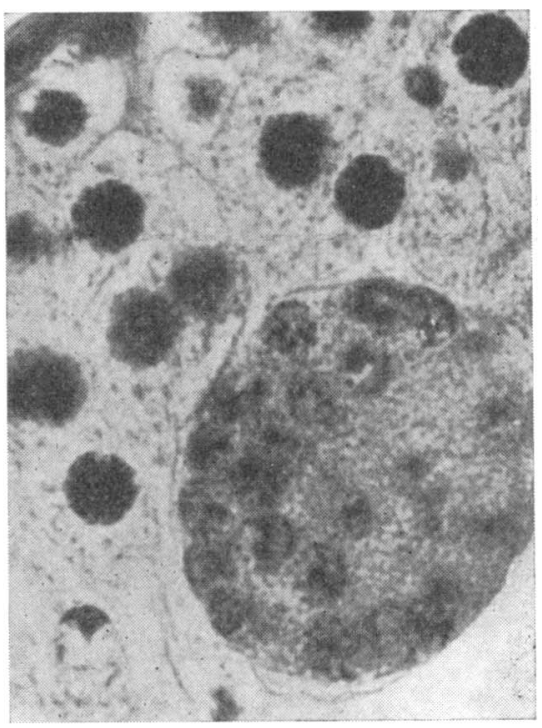

F. i g. 4.

Fig. 3. Multinucleated spermiocyte, Three nuclei in focus at the exposure moment (approx. $3000 \times$ ).

F i g. 4. Giant cell near the lumen of the Tubulus seminiferous (approx. $750 \times$ ).

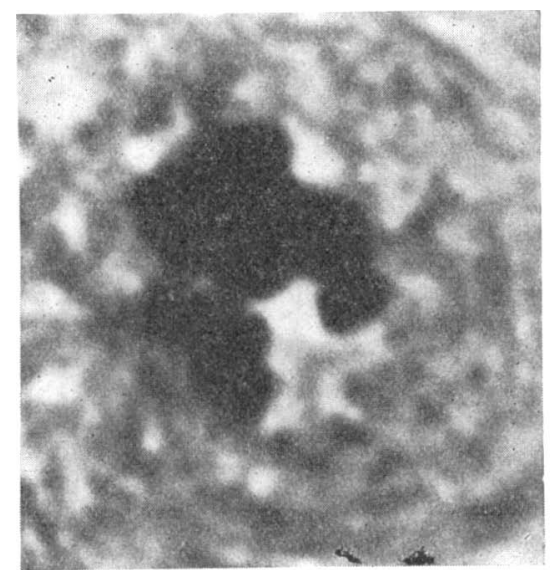

F i g. 5.

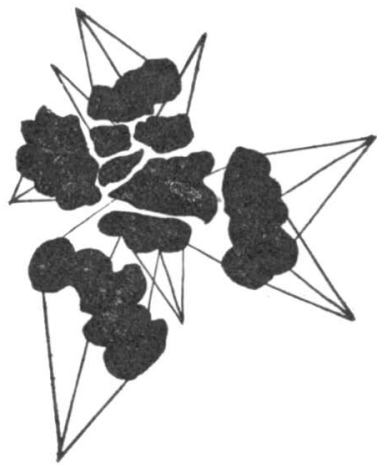

Fig. 6.

F i g. 5. Primary spermiocyte in metaphase with multipolar spindles (since the spindles and the chromosome groups do not lie on one plane, they are not suited to photography) (approx. $3000 \times$ ).

$\mathrm{F}$ i g. 6. Drawing of the cell in fig. 5. 


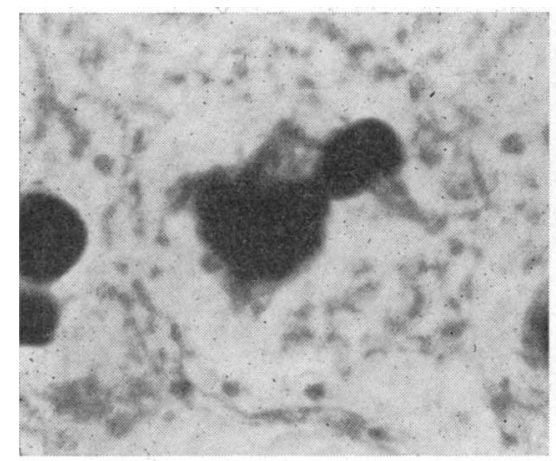

F i g. 7.

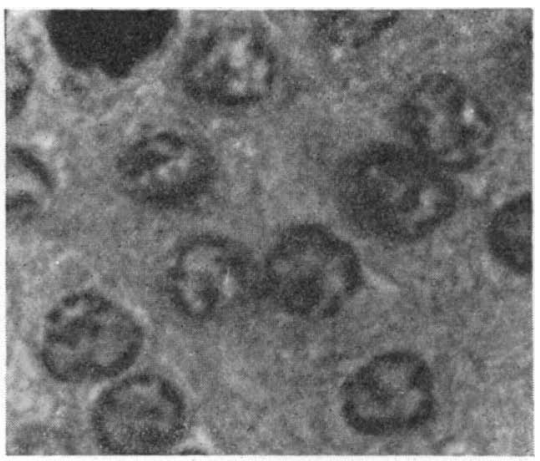

F i g. 8.

F i g. 7. Primary spermiocyte with two spindles approximately lying perpendicular to the microscopelight (approx. $2000 \times$ ).

Fi g. 8. Spermids with abnormal chromatin content

(approx. $1500 \times$ ).

\& Bryne 1960), most cells have the expected morphology. In most of the cells that have attained the end of this stage and in which congression is so far advanced that all chromosomes have approached the equatorial plate, one half of the nuclear spindle divides so that the spindle fibres converge towards two points (centrosomes?) on that side of the equatorial plate. In primary spermiocytes in metaphase, several nuclear spindles can often be seen within a cell (Fig. $5 \& 6$ ). The spatial arrangement of the spindles on several planes makes it impossible to photograph more than 2 spindles in the cell (Fig. 7 ). Cells with only 2 nuclear spindles are actually the exceptions; most have many more. The more numerous the spindles are in a cell the smaller is the equatorial plate for each spindle. The various chromosome groups come to lie in the centre of the cell (Fig. 5) with the corresponding spindles radiating outwards in various directions. Indeed, the appearance suggests that the centrosomes are mutually repulsed (Fig. 6). Chromosome number in cells with multipolar spindles seems to be the same as in a normal primary spermiocyte. This also appears to be the case for the spindle fibres which implies that the number of fibres in each spindle is inversely proportional to the number of spindles in a cell. As the number of spindles rises to 8 or 10 even more, some of these are so small and made up of so few fibres that they can be difficult to detect by the method used here if one does not carefully search for them. This 
is especially the case if the axis of the spindle is more or less parallel to the direction of light in the microscope.

In cells with multipolar spindles the chromosomes displayed no tendency to migrate towards the centrosomes. Occasionally, primary spermiocytes in normal anaphase or telophase have been observed and in these cells the chromosomes have been normally distributed.

Nuclear size of secondary spermiocytes in prophase varies widely as does chromosome morphology. In addition to chromosomes with a morphology normal for this stage, chromosomes can be encountered which most closely resemble bivalents in metaphase of primary spermiocytes, or which resemble shrunken univalent chromosomes of the type seen in interphase of the first meiosis (primary spermiocytes), or fragments of chromosomes which cannot be morphologically ranked in normal spermiocytogenesis. On the other hand, fusion of several bivalents to form large chromosome clumps of the type seen in the germinal epithelium of bulls with sticky chromosomes, (Knudsen 1961) has not been observed.

Whether or not spermiocytes in metaphase containing multipolar nuclear spindles are in first or second meiotic division is uncertain since the abnormal morphology of the spindles and chromosomes makes accurate recognition difficult. The hollow spindles which are so characteristic for secondary spermiocytes in metaphase (Knudsen \& Bryne 1960) have not been identified in cells with multipolar spindles. On the other hand, the greatest diameter of the nuclear spindle being less than the diameter of the corresponding equatorial plate suggests a second meiotic division. In a very few cells, apparently normal metaphase of secondary spermiocytes was seen.

No unequivocal examples of secondary spermiocytes in anaphase or telophase have been encountered.

Large number of spermids are present in the histological sections. Cell borders between the individual spermids are difficult to recognize if they exist at all (Fig. 8). Sometimes a definite cell border can be traced around a group of spermids. These borders can be especially prominent nearer the lumen where undisputable giant cells have been found (Fig. 4). The chromatin in the spermids is usually finely granular and of ten gathered along the nuclear membrane (Fig. 8). Only a very few cells have been seen for which the morphology suggests that transformation 
is under way. Karyopyknosis and karyolysis has occurred in a moderate number of spermids. If several spermid nuclei are enclosed within a common cell membrane, pyknosis and lysis are generally less pronounced than in spermids with solitary nuclei.

\section{DISCUSSION}

The clinical, gross morphological, and histological observations give the diagnosis testicular hypoplasia with arrested spermiogenesis, a type of hypoplasia corresponding that described by Lagerlöf (1948) in the same breed.

Formation of multipolar spindles has been seen during meiosis, and multinucleated cells were present in the later stages of spermiogenesis and even in the ejaculate. Can the spindle abnormality lead to the formation of the giant cells? Similar abnormalities in the nuclear spindle have not previously been demonstrated in meiosis in mammals but Walters (1960), for instance, has observed such defective spindles in interspecific hybrids of Bromus and has suggested a relationship between the spindle irregularities and multinucleated microsporocytes. The germinal epithelium of the bull, however, often reacts to degenerative stimuli by the formation of giant cells. In such states the giant cells seem to be formed by desquamation of spermids (Lagerlöf 1934). Cohrs (1954) suggested that amitotic division resulted in these giant cells or, as he called them, "Symplasmen". With degenerative changes in the germinal epithelium, it should be pointed out, the centrosomes and tips of the spindles are destroyed very easily and early (Knudsen 1954); multipolar nuclear spindles are unlikely to represent a degenerative lesion. The obliterated cell borders often seen among the spermids in the testicles of these bulls may suggest a desquamative process. On the other hand, there is no tendency to release cell groups with clearly viable cells as is seen in degeneration of the germinal epithelium. In fact, in these bulls the nucleus in solitary cells invariably undergoes pyknosis or lysis before being released into the lumen. In short, it is difficult from the histological appearance of the germinal epithelium to represent the giant cells as a degenerative phenomenon. Furthermore, the morphology of giant cells often gives a clue to their origin. Giant cells formed as a reaction to testicular degeneration have nuclei of a more homogeneous 
structure usually located at the periphery of the cell. In bulls with multipolar nuclear spindles, the nuclei of the giant cells are flocculent and irregularly placed in the centre of the cell. Moreover, in these bulls the giant cells were abundant and were seen together with normal sperm in the centrifuge sediment of the ejaculate. As far as can be ascertained, the type of giant cells seen in these 3 bulls has only been encountered in bulls with testicular hypoplasia, further support for a more than chance association between multipolar spindles and these multinucleated cells.

Among the spermids, such manifestations of degeneration as hyperchromasia of the nuclear membrane, karyopyknosis and karyolysis and obliteration of cell borders (Fig. 8) suggest that many cells die during this stage. The pyknotic nuclei and anuclear cell fragments seen in the ejaculate represent this process.

Occasional sperms, often of normal morphology, are present in the ejaculate. This implies that, at least to some degree, spermiogenesis proceeds without abnormalities in the nuclear spindle, cell division, and transformation. One of the bulls it will be remembered was claimed to have sired 2 calves. Sperm morphology is not incompatible with this but successful conception by this bull is certainly an exception to the widespread impression that a certain concentration of sperm is a prerequisite.

Multipolar nuclear spindles have been demonstrated in several plant and insect species. In mammals the abnormality has been described in human cancer cell and now in the germinal epithelium of bull. This paucity of reports for mammals probably represents no more than a comparative lack of study rather than actual rarity. Accordingly it is as yet unknown whether or not intoxications can cause the formation of multipolar spindles in mammals as in plants. The bulls described here were kept under clinical observation long enough for us to be able to eliminate intoxication as a likely cause. A more plausible explanation is a genetic background. With only 3 bulls known to have this defect, a genetic background cannot be proven; it is sufficient to note the close relationship of the bulls and their degree of in-breeding.

For bulls with hypoplastic testicles characterised by differentiated germinal epithelium and inability to form sperm, two quite different aetiological pathways have been demonstrated multipolar nuclear spindles and sticky chromosomes (Knudsen 1961). Both types have characteristic traces in the ejaculate of 
the pathological processes in the germinal epithelium which can be demonstrated by cytogenetic methods. Diagnosis then, in these cases can be established without going to the extreme of castration or slaughter. Since these disturbances of spermiogenesis most likely are hereditary, in any event they were observed in highly in-breed bulls, early diagnosis is obviously important. Stickiness and multipolar nuclear spindles are undoubtedly not the only abnormalities which can produce testicular hypoplasia of this type. Further cytogenetic studies can be expected to give more information about testicular hypoplasia which can be of practical importance for breeding programmes.

\section{REFERENCES}

Beadle, G. W., and Barbara Mc Clintock: Science, 1928, 68, 433.

Cohrs, P.: Dtsch. Akad. der Landwirtschaftswissensch. Berlin, 1957, Tagungsberichte Nr. 10, 35.

Ehrenberg, L., and G. östergren: Bot. Not. 1942, 203.

Heitz, E.: Planta (Berl), 1926, 1, 241.

Knudsen, O.: Acta path. microbiol. scand., 1954, Suppl. 101.

Knudsen, O.: Int. J. Fertil., 1958, 3, 389.

Knudsen, O.: Acta vet. scand. 1961, $2,1$.

Knudsen, O., and N. Bryne: Acta vet. scand., 1960, 1, 140.

Koller, P. C.: Proc. roy. Soc. Edinb. 1934, 54, 67.

Lagerlöf, N.: Acta path. microbiol. scand. 1934, Suppl. 19.

Lagerlöf, N.: I Int. Congr. of Phys. path. of Animal Reprod. Milano 1948.

Melander, Y., and K. G. Wingstrand: Stain Techn. 1953, 28, 217.

Nelson, W. O.: Fertil \& Steril. 1950, 6, 477.

Pease, D. C.: Biol. Bull. 1946, 91, 145.

Sakamura, T.: J. Coll. Sci. Imp. Univ. Tokoy 1920, 39, 1.

Schrader, F.: J. Morph. 1941, 68, 123.

Sniffen, R. C., Howard, R. P., and Simmons, F. A.: Arch. Path. 1950, $50,285$.

Therman, Eeva and S. Timonen: Hereditas (Lund) 1954, 40, 313.

Walters, Marta S.: Amer. J. Bot. 1958, 45, 271.

Walters, Marta S.: Chromosoma (Berl) 1960, 11, 167.

\section{SUMMARY}

Formation of multipolar nuclear spindles in spermiocytes has been demonstrated in three highly in-bred and closely related bulls with a type of testicular hypoplasia which can be summarised as arrested spermiogenesis. The spindle abnormality can be assumed to be the cause of the disturbance in spermiogenesis and to be associated with the formation of characteristic giant cells in later stages of spermiogenesis and their presence in the ejaculate. The ejaculate is 
watery and the centrifuges sediment contains giant cells with two to more than ten flocculent nuclei as well as solitary pyknotic nuclei and a few sperm with normal morphology.

Two of these bulls had served more than twenty times; according to the breeder one bull produced two calves in spite of his oligospermia.

\section{ZUSAMMENFASSUNG}

Hodenhypoplasie mit multipolären Kernspulen in den Spermiozyten bei Bullen.

Multiple Kernspulen in den Spermiozyten hat man bei drei eingezuchteten und nahe verwandten Bullen mit einer Art Hodenhypoplasie, die wohl als 'arrested spermiogenesis' betrachtet werden kann, zeigen können.

Man vermutet, dass der Kernspulendefekt der Grund zu den Störungen in der Spermiogenese ist und in Relation zu dem Vorkommen karakteristischer sogenannten Riesenzellen in den letzteren Stadien der Spermiogenese wie auch im Ejakulat steht. Das Ejakulat ist wässerich dünn. Bezeichnend für das Spermazentrifugat sind Riesenzellen mit zwei bis einige zehn Kernen mit flockigem Inhalt, meistens in der Zellmitte liegend, weiterhin pyknotische Kerne und einzelne Spermie mit gewöhnlicherweise normaler Morphologie.

Zwei der infragestehenden Bullen haben jeder ungefähr 20 Deckungen ausgeführt, wonach die Deckungen des einen Bullen nach Mitteilung zu zwei Trächtigkeiten führten, trotzdem dieser Bulle Oligospermie hatte.

\section{SAMMANFATTNING}

\section{Testikelhypoplasi med multipolära kärnspolar $i$ spermiocyterna} hos tjur.

Multipolära kärnspolar i spermiocyterna har påvisats hos tre starkt inavlade och närbesläktade tjurar med en typ av testikelhypoplasi som närmast kan karakteriseras som 'arrested spermiogenesis'. Kärnspoledefekten förmodas vara orsak till rubbningen i spermiogenesen och stå i relation till förekomsten av karakteristiska s. k. jätteceller i senare stadier av spermiogenesen och i ejakulatet. Ejakulatet är vattnigt tunt. Spermacentrifugatet karakteriseras av jätteceller med två till c:a ett tiotal kärnor med flockigt innehåll, oftast placerade i mitten av cellen, pyknotiska kärnor och enstaka spermier oftast med normal morfologi. Två av tjurarna ha vardera utfört c:a 20 betäckningar, varvid den ena tjuren enligt uppgift lämnat 2 dräktigheter, trots att den var behäftad med oligospermi. 